Original Research Paper

\title{
Pemberdayaan Masyarakat Desa Mujur Kecamatan Praya Timur Melalui Pemanfaatan dan Pelatihan dalam Mengolah Sampah Plastik Menjadi Kerajinan Tangan
}

\author{
M. Hasan Murdani ${ }^{1}$, Nadilla Yasmiadi ${ }^{2}$, Yuliatin $^{3}$, Dadi Setiadi ${ }^{4}$ \\ ${ }^{1}$ Pendidikan Sosiologi, Fakultas Keguruan dan Ilmu Pendidikan, Universitas Mataram, Mataram, Indonesia; \\ ${ }^{2}$ Pendidikan Matematika, Fakultas Keguruan dan Ilmu Pendidikan, Universitas Mataram, Mataram, Indonesia; \\ ${ }^{3}$ Pendidikan Biologi, Fakultas Keguruan dan Ilmu Pendidikan, Universitas Mataram, Mataram, Indonesia; \\ ${ }^{4}$ Dosen Pendidikan Biologi, Fakultas Keguruan dan Ilmu Pendidikan, Universitas Mataram, Mataram, \\ Indonesia
}

https://doi.org/10.29303/jpmpi.v3i2.1446

Sitasi: Murdani, M. H., Yasmiadi, N., Yuliatin \& Setiadi, D. (2022). Pemberdayaan Masyarakat Desa Mujur Kecamatan Praya Timur Melalui Pemanfaatan dan Pelatihan dalam Mengolah Sampah Plastik Menjadi Kerajinan Tangan.Jurnal Pengabdian Magister Pendidikan IPA, 5(1).

\section{Article history}

Received: 21 Januari 2022

Revised: 30 Januari 2022

Accepted: 27 Februari 2022

*Corresponding Author: M.

Hasan Murdani, Pendidikan Sosiologi, Fakultas Keguruan dan Ilmu Pendidikan,

Universitas Mataram, Mataram, Email:

m.hasanmurdani@gmail.com

\begin{abstract}
Sampah di Desa Mujur merupakan salah satu masalah yang belum terselesaikan hingga saat ini. Kurangnya kesadaran masyarakat tentang pengelolaan sampah mengakibatkan pencemaran dan kerusakan lingkungan, khususnya pada pengolahan limbah sampah plastik. Untuk itu pentingnya pengadaan penyuluhan pemanfaatan limbah sampah dan pelatihan pembuatan kerajinan tangan dengan menggunakan sampah plastik. KKN Terpadu Unram mengusung program pemanfaatan daur ulang sampah plastik agar dapat digunakan kembali atau diolah menjadi barang yang bermanfaat bagi lingkungan sekitar. Tujuan dari program ini adalah memberdayakan masyarakat Desa Mujur dalam pengolahan sampah menjadi kerajinan tangan menggunakan sampah plastik. Metode yang digunakan berupa pelatihan yang lebih berbasis pada praktik langsung, sosialisasi dan pembimbingan yang sifatnya monitoring. Hasil menunjukan bahwakegiatan tersebut dapat mengurangi limbah plastik dan juga dapat mengasah kreativitas masyarakat Desa Mujur saat mengisi waktu luang dirumah.
\end{abstract}

Keywords: pemanpaatan, pelatihan, mengolah, sampah plastik.

\section{Pendahuluan}

Menurut UU Nomor 18 Tahun 2008 tentang pengolahan sampah, dijelaskan bahwa sampah merupakan permasalahan nasional sehingga pengolahannya perlu dilakukan secara komprehensif dan terpadu dari hulu ke hilir agar memberikan manfaat secara ekonomi, sehat bagi masyarakat, dan aman bagi lingkungan, serta dapat mengubah perilaku masyarakat. Sampah dapat dibagi menjadi dua, yakni sampah organik dan anorganik. Sampah organik adalah sampah yang berasal dari sisa makhluk hidup yang mudah terurai secara alami tanpa proses campur tangan manusia untuk dapat terurai. Sedangkan sampah anorganik adalah sampah yang sudah tidak dipakai lagi dan sulit untuk terurai.

Sampah plastik merupakan salah satu sampah non organik yang paling banyak dihasilkan, misalnya dari rumah tangga, laut, pegunungan, dan sekolah (Indartik dkk, 2018). Plastik yang bersifat tidak dapat terurai hingga lebih dari 100 tahun jika tidak dikelola dengan baik tentunya akan 
berdampak buruk bagi lingkungan dan kesehatan masyarakat. Akibat dari sampah plastik diantaranya tercemarnya tanah dan air, pemanasan global, polusi pada udara dan lain-lain. Plastik mudah terbakar, sehingga mengakibatkan ancaman terjadinya kebakaran pun semakin meningkat. Asap hasil pembakaran bahan plastik sangat berbahaya karena mengandung gas-gas beracun seperti hidrogen sianida $(\mathrm{HCN})$ dan karbon monoksida (CO). Hidrogen sianida berasal dari polimer berbahan dasar akrilonitril, sedangkan karbon monoksida sebagai hasil pembakaran tidak sempurna. Hal inilah yang menyebabkan sampah plastik sebagai salah satu penyebab pencemaran udara dan mengakibatkan efek jangka panjang berupa pemanasan secara global pada atmosfer. Data yang dirilis oleh Dinas LHK dan BPBD provinsi NTB, produksi sampah plastik pada tahun 2021 adalah sebesar $80 \%$ atau yang masih belum bisa dikelola adalah sekitar 3.388,76 ton per hari.

Permasalahan sampah di Indonesia merupakan masalah yang belum terselesaikan hingga saat ini, sementara itu dengan bertambahnya jumlah penduduk maka akan mengikuti pula bertambahnya volume sampah yang dihasilkan dari aktivitas manusia. Sampah merupakan masalah utama yang dihadapi oleh masyarakat yang ada di Desa Mujur Kecamatan Praya Timur, hal ini dikarenakan sistem pengelolaan persampahan yang buruk bahkan tidak tersedianya sarana pengumpulan sampah sementara (TPS) sehingga budaya perilaku masyarakat yang ada di Desa Mujur Kecamatan Praya Timur dalam Penanganan sampah dengan cara membakar dan menimbun di dalam tanah sehingga dapat menimbulkan dampak negatif bagi lingkungan maupun secara langsung terhadap kesehatan masyarakat setempat.

Plastik merupakan salah satu sampah yang dapat didaur ulang. Selama ini plastik yang telah tidak dipakai lagi dibuang begitu saja, yang akhirnya akan mencemarkan lingkungan. Meski limbah kertas termasuk limbah yang dapat diurai, akan tetapi membutuhkan waktu yang lama untuk menjadi tanah. Padahal limbah plastik dapat diolah menjadi beraneka barang kerajinan yang menarik dan bermanfaat serta bernilai jual tinggi karena memiliki tekstur dan warna yang beragam dan indah. Dari plastik daur ulang kita dapat membuat beraneka ragam kerajinan tangan (Aminudin dan Nurwati, 2019). Cara pengolahan dan pembuatannya juga relatif mudah dan siapa saja bisa melakukannya. Kerajinan plastik daur ulang sangat mungkin diberikan kepada Ibu PKK, Ibu Kader Desa Mujur dan Remaja Dusun Berenyok. Sebagai pemanfaatan daur ulang sampah, ibu PKK, ibu kader Desa Mujur dan Remaja Dusun Berenyok dapat berkreasi dengan menciptakan berbagai macam kerajinan dari plastik yang didaur ulang, contohnya bisa menjadi pot bunga, tempat pensil, gantungan jilbab, bros dan bunga. Dengan demikian selain dapat meminimalisir jumlah sampah di lingkungan sekitar, keterampilan ini dapat menjadi wahana berkreasi yang kreatif bagi Ibu PKK, Ibu Kader Desa Mujur dan Remaja Dusun Berenyok.

Hasil yang diharapkan dari penelitian ini adalah dapat memberikan pengetahuan mengenai cara pengolahan sampah plastik, menambah nilai guna terhadap sampah-sampah non organik, dan dapat mengurangi ketergantungan masyarakat terhadap penggunaan sampah plastik.

\section{Metode}

Pendekatan yang akan digunakan dalam kegiatan pengolahan sampah plastik menjadi kerajinan tangan yaitu kegiatan berupa pelatihan yang lebih berbasis pada praktik langsung, sosialisasi dan pembimbingan yang sifatnya monitoring.Tahapan pemberdayaan masyarakat dalam Mengolah Sampah Plastik Menjadi Kerajinan akan dilakukan sebagai berikut: tahap sosialisasi mencakup pemberian pembekalan ataupun penyuluhan kepada masyarakat berupa pemahaman tentang bahaya limbah sampah plastik bagi lingkungan yang diharapakan dapat memberikan kesadaran bagi masyarakat pentingnya pengolahan sampah plastik. Penyuluhan ini diadakan untuk menumbuhkan dan meningkatkan kesadaran masyarakat mengenai bagaimana menjaga kebersihan lingkungan dengan memanfaatkan sampah plastik menjadi sebuah kerajinan tangan.Tahap praktik langsung mancakup pengumpulan alat dan bahan yang dibutuhkan untuk pembuatan kerajinan tangan dan diberikan panduan cara pembuatannya. Kemudian masyarakat yang berpartisipasi mempraktikkan cara membuat kerajinan tangan dari sampah plastik.Tahap pembimbingan yang sifatnya monitoring merupakan tahap dimana masyarakat yang ikut berpartisipasi melaksanakan sendiri bagaimana pembuatan kerajinan tangan dari sampah plastik. Kemudian tim KKN terpadu Unram memberikan 
bimbingan dan arahan bagaimana membuat kerajinan tangan tersebut sehingga prosesnya lebih baik dan mudah untuk mecapai tujuan yang ditargetkan.Setelah semua tahap dilaksanakan maka untuk mengukur tingkat ketercapaiannya yaitu dengan melihat bagaimana hasil akhir dari pembuatan kerajinan tangan berbahan dasar sampah plastik dan melihat bagaimana partisipasi masyarakat dalam mengikuti pelatihan dari awal sampai akhir.

\section{Hasil dan Pembahasan}

Pembahasan terhadap hasil penelitian dan pengujian yang diperoleh disajikan dalam bentuk uraian teoritik, baik secara kualitatif maupun kuantitatif. Hasil percobaan sebaiknya ditampilkan dalam berupa grafik atau pun tabel. Untuk grafik dapat mengikuti format untuk diagram dan gambar.

Hasil evaluasi kegiatan pemberdayaan masyarakat melalui pemanfaata dan pelatihan dalam mengolah sampah plastik di Desa Mujur khususnya Dusun Berenyok menunjukkan bahwa peserta pelatihan masih kurang mampu dalam mendaur ulang sampah karena kurannya wawasan, pemahaman, dan kreatifitas terkait bagaimana cara dalam mengolah sampah menjadi barang yang dapat dimanfaatkan. Kegiatan ini dilakukan untuk memberikan pemahaman tentang pengolahan limbah sampah plastik menjadi kerajinan tangan dan diberikan langkah-langkah pembuatan kerajinan tangan secara terstruktur serta melibatkan langsung semua kalangan masyarakat. Pelaksanaan program pemberdayaan masyarakat dimulai dengan persiapan program yang meliputi survei lokasi. Hasil survey menunjukkan bahwa kendala yang dihadapi masyarakat Desa Mujur antara lain:

1) Tidak adanya lokasi pembuangan atau pengumpulan sampah sementara, 2) banyak volume sampah setiap harinya, 3) tidak adanya alat penghancur sampah. Tahap selanjutnya adalah persiapan instrumen monitoring dan evaluasi yaitu pengetahuan masyarakat, selanjutnya pembahasan program bersama masyarakat Desa Mujur, kecamatan praya timur, Kabupaten Lombok Tengah.

KKN Terpadu Unram mengusung program pemanfaatan daur ulang sampah plastik agar dapat digunakan kembali dengan tujuan membantu masyarakat Desa Mujur dalam pengolahan sampah menjadi kerajinan tangan menggunakan sampah plastik. Metode yang digunakan berupa pelatihan yang lebih berbasis pada praktik langsung, sosialisasi dan pembimbingan yang sifatnya monitoring. Setelah melakukan tahap awal yaitu sosialisasi, KKN Terpadu Unram mengajak masyarakat Desa Mujur Khususnya di dusun berenyok untuk ikut berpartisipasi dalam kegiatan mengolah sampah menjadi kerajinan tangan. Masyarakat memberikan dukungan dengan ikut serta dalam kegiatan tersebut. Kegiatan ini diadakan dalam 2 kali pertemuan, pertemuan pertama kami memberikan sosialisasi.

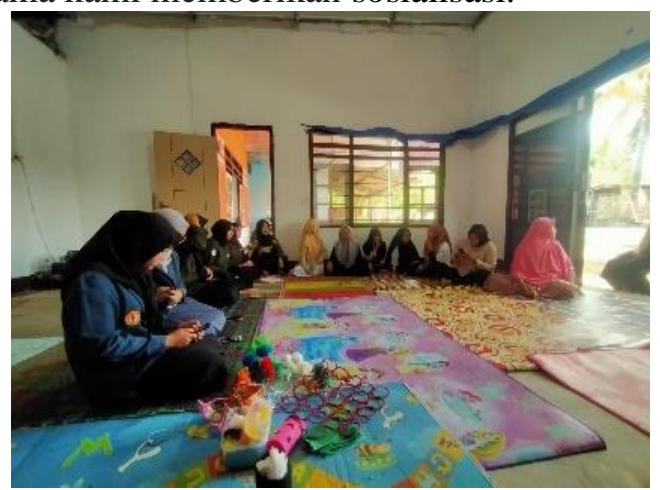

Gambar 1 Sosialisasi

Pemberian sosialisasi mencakup pemberian penyuluhan kepada masyarakat berupa pemahaman tentang bahaya limbah sampah plastik bagi lingkungan yang diharapakan dapat memberikan kesadaran bagi masyarakat pentingnya pengolahan sampah plastik. Penyuluhan ini diadakan untuk menumbuhkan dan meningkatkan kesadaran masyarakat mengenai bagaimana menjaga kebersihan lingkungan dengan memanfaatkan sampah plastik menjadi sebuah kerajinan tangan. Setelah diberikan penyuluhan masyarakat memiliki gambaran bagaimana cara mengolah sampah plastik menjadi kerajinan tangan dan bahanapa yang akan digunakan. Penyuluhan sampah dan pelatihan pembuatan Kerajinan tangan di desa mujur dilakukan bersama Ibu PKK, Ibu Kader Desa Mujur dan Remaja Dusun Berenyok. Penyuluhan pertama tentang pengenalan kerajinan tangan, yang dimana dihadiri oleh Ibu PKK, Ibu Kader Desa Mujur. Penyuluhan ini diadakan untuk menumbuhkan dan meningkatkan kesadaran masyarakat mengenai kebersihan lingkungan agar dapat memanfaat sampah plastik menjadi sebuah kerajinan tangan. 


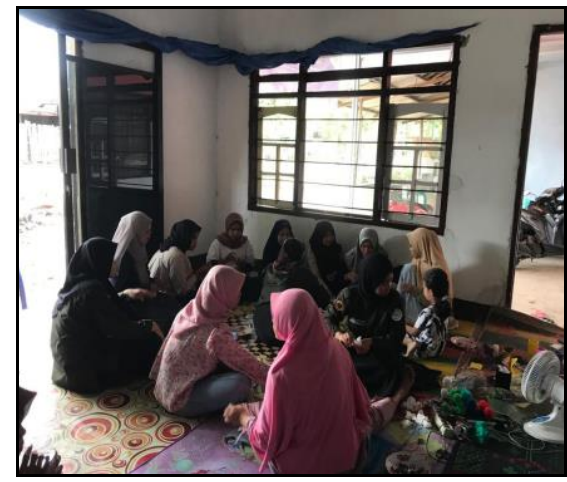

Gambar 2 Pelatihan Kerajinan Tangan

Pelatihan kedua yaitu mengenai pelatihan membuat kerajinan tangan bersama Ibu PKK, Ibu Kader Desa Mujur dan Remaja Dusun Berenyok. Kegiatan ini dilaksanakan dengan memanfaatkan sampah plastic sebagai upaya pengelolaan sampah dapat berguna bagi masyarakat khususnya bagi masyarakat di desa mujur kecamatan praya timur. Pelatihan ini bertujuan untuk memberdayakan masyarakat Desa Mujur dalam pengolahan sampah menjadi kerajinan tangan menggunakan sampah plastik

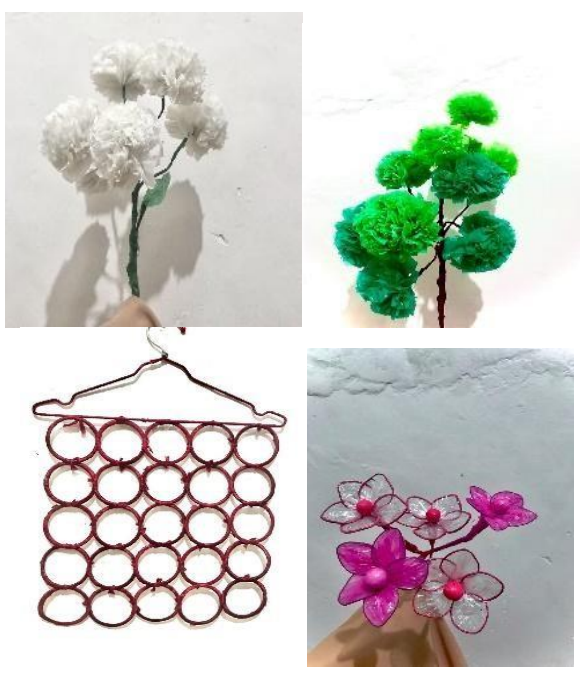

Gambar 3 Hasil Kerajinan Tangan

Hasil dari pemperdayaan Masyarakat Desa Mujur Kecamatan Praya Timur melalui pemanfaatan dan pelatihan dalam mengolah sampah plastik menjadi kerajinan tangan yaitu tim KKN TerpaduUnram dan masyarakat Desa Mujur sudah bisa mengolah sampah plastic menjadi kerajinan tangan berupa bunga yang dibuat dari plastik bekasdan gantungan jilbab yang terbuat dari gelas plastik. Dengan demikian tujuan dari program memberdayakan masyarakat Desa Mujur dalam pengolahan sampah menjadi kerajinan tangan menggunakan sampah plastic sudah terlaksana dengan baik.

\section{Kesimpulan}

Semua peserta pelatihan kerajina tangan di Desa Mujur khususnya di Dusun Berenyok belum sepenuhnya memeliliki keterampilan dalam memanfaatkan sampah plastik. Pemanfaatan sampah pastik melalui pelatihan kerajinan tangan dapat memberikan solusi terhadap masalah kurangnya pengetahuan mengenai cara pengolahan sampah plastik, menambah nilai guna terhadap sampah-sampah non organik, dan dapat mengurangi ketergantungan masyarakat terhadap penggunaan sampah plastik.

Berdasarkan hasil evaluasi terhadap pencapaian dan manfaat kegiatan pelatihan kerajinan tangan yang dilaksanakan ini dapat dapat di simpulkan berbagi berikut:

1) Dengan dilaksanakannya program pelatihan di Desa Mujur Kecamatan Praya Timur Kabupaten Lombok Tengah terjadi peningkatan pemahaman masyarakat tentang bagaimana cara pengolahan sampah agar dapat dimanfaatkan untuk kebutuhan hidupnya.

2) Adapun untuk menambah nilai guna terhap sampah-sampah non organic dilakukan pelatihan kerajinan tangan dengan membuat berbagai barang yang dapat digunakan sepeti bunga dan gantungan jilbab.

3) Adapun pencapaian manfaat kegiatan yang dilakukan melalui pelatihan pengolahan sampah menjadi kerajinan tangan dapat diukur dengan besarnya antusias masyarakat dalam mengikuti kegiatan dari awal sampai akhir.

\section{Saran}

Diharapkan peneliti selanjutnya untuk lebih meningkatkan efektifitas pemanfaatan dan pelatihan pengolahan sampah menjadi kerajinan tangan mengingat besarnya penggunaan plastik di masyarakat.

\section{Ucapan Terima Kasih}

Terimakasih disampaikan kepada dosen pembimbing lapangan atas dukungannya selama pelaksanaan kegiatan KKN, kepala Desa Mujur, perangkat desa serta masyarakat yang sudah berpartisipasi dalam kegiatan kami selama kegiatan KKN. 


\section{Daftar Pustaka}

Aminudin, \& Nurwati. (2019). pemanfaatan sampah plastik menjadi kerajinan tangan guna meningkatkan kreatifitas warga sekitar institut teknologi dan bisnis ahmad dahlan (ITB-AD)JAKARTA. JURNAL ABDIMAS BSI, 67-68.

Anggun , B. S., Mita Arianie, D., Aditya Andi Risman , V., Handayani, W., \& Sri Kawuryan, I. (2019). pengolahan sampah plastik di salatiga : praktik dan tantangan . jurnal ilmu lingkungan , 90-91.

Kurniawidi, D., ardianto, t., syamsuddin, alaa, s., ikhsan, a., \& rahayu, s. (2021). pemilahan sampah plastik untuk mendukung program zero waste pada pusat daur ulang sampah bajang peripih doro, pringgarata, lombok tengah tahun 2021. jurnal pengabdian magister pendidikan IPA , 404.

Purwaningrum, p. (2016). upaya mengurangi timbulan sampah plastik di lingkungan . JTL, 142.

Sahil, J., Muhdar, M., Rohman, F., \& Istamar Syamsuri. (2016). Sistem Pengolahan Dan Penanggulangan Sampah Di Kelurahan Dufa-Dufa Kota Ternate. Jurnal Bio Edukasi, 479.

wahyudi, j., prayitno, h., \& astuti, a. (2018). pemanfaatan limbah plastik sebagai bahan baku pembuatan bahan bakar alternatif. jurnal litbang, 59.

Yuriandala, H. P. (2010). Studi Pemanfaatan Sampah Plastik Menjadi Produk dan Jasa Kreatif. Jurnal sains dan teknologi lingkungan volume 2 no 1, 22. 